\title{
Peran Literasi dalam Pengembangan Kemampuan Berpikir Kritis
}

\section{The Role of Literacy in the Development of Critical Thinking Abilitie}

\author{
Oktariani( $^{(1)}$ \& Evri Ekadiansyah ${ }^{(2)}$ \\ (1)Fakultas Psikologi, Universitas Potensi Utama, Indonesia \\ (2) Fakultas Teknik dan Ilmu Komputer, Universitas Potensi Utama, Indonesia \\ Diterima : 7 April 2020; Disetujui : 14 April 2020; Dipublish : 30 April 2020 \\ *Corresponding author: Email: oktariani1610@gmail.com
}

\begin{abstract}
Abstrak
Literasi merupakan kemampuan seseorang menggunakan potensi dan keterampilan dalam mengolah dan memahami informasi saat melakukan aktivitas membaca dan menulis. Melalui kemampuan literasi, seseorang tidak saja memperoleh ilmu pengetahuan tetapi juga bisa menggunakan ilmu pengetahuaan dan pengalamannya untuk dijadikan rujukan di masa yang akan datang. Berpikir kritis merupakan proses berpikir intelektual di mana pemikir dengan sengaja menilai kualitas membuat keputusan ketika menggunakan semua keterampilan tersebut secara efektif dalam konteks dan tipe yang tepat.pemikirannya, pemikir menggunakan pemikiran yang reflektif, independen, jernih, dan rasional. Dengan kemampuan literasi yang baik, maka diharapkan kemampuan berpikir kritispun akan meningkat. Kemampuan berpikir kritis merupakan suatu proses berpikir yang dapat diterima akal reflektif yang diarahkan untuk memutuskan apa yang dikerjakan atau diyakini, dalam hal ini tidak sembarangan, tidak membawa ke sembarang kesimpulan tetapi kepada ke kekesimpulan yang terbaik. . Dan hal ini berkaitan dengan kemampuan seseorang dalam literasi, dengan literasi yang dilakukan individu seperti dengan membaca atau menyimak informasi atau cerita, maka individu dapat menemukan cara dalam menyelesaikan masalah, sehingga individu akan melakukan analisis dari permasalahannya tersebut, sehingga pada akhirnya akan membentuk karakter atau pribadi yang kritis.
\end{abstract}

Kata kunci : Literasi; Berpikir Kritis.

\begin{abstract}
Literacy is a person's ability to use their potential and skills in processing and understanding information when reading and writing. Through literacy skills, a person not only acquires knowledge but can also use his knowledge and experience to be used as a reference in the future. Critical thinking is an intellectual thought process in which thinkers deliberately assess the quality of making decisions when using all of these skills effectively in the right context and type. Thinkers, thinkers use reflective, independent, clear, and rational thinking. With good literacy skills, it is expected that even critical thinking skills will increase. The ability to think critically is an acceptable thought process of reflective reasoning directed to decide what to do or believe, in this case not carelessly, not leading to any conclusions but to the best conclusions. . And this is related to the ability of a person in literacy, with literacy by individuals such as by reading or listening to information or stories, then individuals can find ways to solve problems, so individuals will do an analysis of these problems, so that in the end they will form characters or personal the critical one.
\end{abstract}

Keywords: Literacy; Critical Thinking.

Rekomendasi mensitasi :

Oktariani \& Ekadiansyah, E. (2020). Peran Literasi dalam Pengembangan Kemampuan Berpikir Kritis. Jurnal Penelitian Pendidikan, Psikologi dan Kesehatan (J-P3K), 1 (1): 23-33. 


\section{PENDAHULUAN}

Pada saat ini perkembangan ilmu pengetahuan dan teknologi yang sangat pesat dan persaingan yang sangat ketat menuntut individi untuk dapat mampu belajar menguasai berbagai ilmu dan teknologi dengan cepat. Jika tidak, maka individu akan tertinggal dan kalah dalam kompetisi di dalam berbagai bidang. Ilmu pengetahuan dan teknologi dapat dipelajari manusia dengan penggunaan penguasaan literasi (keaksaraan dan kewicaraan) yang memadai. Kemampuan literasi yang tinggi dapat mendorong perkembangan ilmu pengetahuan dan teknologi ke arah tingkatan yang lebih tinggi lagi.

Literasi merupakan kemampuan seseorang menggunakan potensi dan keterampilan dalam mengolah dan memahami informasi saat melakukan aktivitas membaca dan menulis.

Namun literasi tidak hanya sekadar kemampuan membaca dan menulis, tetapi literasi bisa berarti melek teknologi, politik, berpikir kritis, dan peka terhadapi lingkungan sekitar. Menurut Kirsch \& Jungeblut dalam buku Literacy: Profile of America's Young Adult mendefinisikan literasi sebagai kemampuan seseorang dalam menggunakan informasi untuk mengembangkan pengetahuan sehingga mendatangkan manfaat bagi masyarakat ( dalam Irianto dan Febrianti, 2016).

Hal tersebut dapat menjadikan seseorang menjadi literat yang dibutuhkan oleh bangsa ini, agar Indonesia dapat bangkit dari keterpurukan sehingga bersaing dan hidup sejajar dengan bangsa lain. Pentingnya kesadaran berliterasi juga akan sangat mendukung keberhasilan seseorang dalam menangani berbagai persoalan.

Melalui kemampuan literasi, seseorang tidak saja memperoleh ilmu pengetahuan tetapi juga bisa menggunakan ilmu pengetahuaan dan pengalamannya untuk dijadikan rujukan di masa yang akan datang. Hal ini sejalan dengan sebuah tulisan di surat kabar Kompas (edisi 1 Juni 2016) yang menyinggung baca tulis termasuk kemampuan strategis yang harus dimiliki bila ingin menjadi bangsa yang maju.

Keterampilan literasi memiliki pengaruh penting bagi keberhasilan seseorang. Keterampilan literasi yang baik akan membantu sesorang dalam memahami informasi baik lisan maupun tertulis. Dalam kehidupan, penguasaan literasi sangat penting dalam mendukung kompetensi-kompetensi yang dimiliki. Kompetensi tersebut dapat saling mendukung apabila seseorang dapat menguasai literasi serta dapat memilah informasi yang dapat mendukung keberhasilan hidup mereka.

Sehubungan dengan hal tersebut, salah satu kompetensi yang harus dimiliki oleh seseorang yang handal adalah menjadi seseorang yang literat. Artinya, keterampilan literasi (membaca dan menulis) yang dimiliki haruslah lebih mendominasi daripada keterampilan orasinya (menyimak dan berbicara).

Kemampuan literasi yang tinggi sangat berpengaruh terhadap pemerolehan berbagai informasi yang berhubungan dengan usaha menjalani kehidupan (berkompetisi). Dengan memiliki informasi sebanyak-banyaknya akan membuat seseorang tidak hanya 
mampu menjalani hidupnya tetapi juga mampu menghargai hidup dan berkontribusi terhadap kemajuan bangsanya.

Hasan (Farihatin, 2013) mengemukakan bahwa kemampuan literasi dasar memiliki peran penting dalam kehidupan seseorang untuk kesuksesan akademiknya. Kemampuan literasi inilah yang harus menjadi senjata utama bagi generasi bangsa Indonesia dan harus diajarkan sejak usia dini.

Dewasa ini, permasalahan literasi merupakan salah satu masalah yang harus mendapat perhatian khusus oleh bangsa Indonesia. Hal ini dikarenakan dalam beberapa dekade terakhir ini, daya saing bangsa Indonesia di tengah bangsa-bangsa lain cenderung kurang berkompetisi.

Realita ini tercermin dalam perbandingan Indeks Pembangunan Manusia (IPM). Tjalla (2011) mengemukakan beberapa penelitian internasional yang menggambarkan kondisi ini adalah seperti penelitian yang dilakukan oleh Programme for International Students Assessment (PISA) terhadap kemampuan literasi (matematika, sains, dan bahasa) seseorang dari berbagai dunia berturutturut pada tahun 2003, 2006, 2009, dan 2012.

Khusus untuk literasi bahasa, tahun 2003 prestasi literasi membaca seseorang Indonesia berada pada peringkat ke-39 dari 40 negara, tahun 2006 pada peringkat ke-48 dari 56 negara, tahun 2009 pada peringkat ke-57 dari 65 negara, dan tahun 2012 pada peringkat ke-64 dari 65 negara.

Penelitian selanjutnya adalah penelitian yang dilakukan oleh Progress in
International Reading Literacy Study (PIRLS) pada tahun 2006. PIRLS melakukan kajian terhadap 45 negara maju dan berkembang dalam bidang membaca pada anak-anak kelas IV sekolah dasar di seluruh dunia di bawah koordinasi The International Association for the Evaluation of Educational Achievement (IEA) dan memperoleh hasil yang menempatkan Indonesia pada peringkat ke 41 (dalam Kharizmi, 2015).

Kemampuan berpikir kritis merupakan kemampuan yang sangat esensial, dan berfungsi efektif dalam semua aspek kehidupan. Oleh karena itu, kemampuan berpikir kritis ini menjadi sangat penting sifatnya dan harus ditanamkan sejak dini baik di sekolah, di rumah maupun di lingkungan masyarakat.

Dalam proses pembelajaran untuk mencapai hasil yang optimal dibutuhkan berpikir secara aktif. Hal ini berarti proses pembelajaran yang optimal membutuhkan pemikiran kritis dari si pembelajar. Oleh karena itu, berpikir kritis sangat penting dalam proses kegiatan pembelajaran.

Dimana berpikir kritis merupakan usaha yang sengaja dilakukan secara aktif, sistematis, dan mengikuti prinsip logika serta mempertimbangkan berbagai sudut pandang untuk mengerti dan mengevaluasi suatu informasi dengan tujuan apakah informasi itu diterima, ditolak atau ditangguhkan penilaiannya (Susanto , 2013).

Selanjutnya menurut Zubaidah dalam Susanto (2013) berpikir kritis adalah suatu kemampuan yang dimiliki individu untuk melihat dan memecahkan masalah yang ditandai dengan sifat-sifat dan bakat kritis yaitu mempunyai rasa ingin tahu yang tinggi imajinatif dan selalu 
tertantang oleh kemajemukan, berani mengambil resiko, dan mempunyai sifat yang tak kalah adalah selalu menghargai hak-hak orang lain, arahan bahkan bimbingan orang lain.

Berpikir kritis merupakan proses berpikir intelektual di mana pemikir dengan sengaja menilai kualitas membuat keputusan ketika menggunakan semua keterampilan tersebut secara efektif dalam konteks dan tipe yang tepat.pemikirannya, pemikir menggunakan pemikiran yang reflektif, independen, jernih, dan rasional.

Menurut Halpen (dalam Achmad, 2007), berpikir kritis adalah memberdayakan keterampilan atau strategi kognitif dalam menentukan tujuan. Proses tersebut dilalui setelah menentukan tujuan, mempertimbangkan, dan mengacu langsung kepada sasaranmerupakan bentuk berpikir yang perlu dikembangkan dalam rangka memecahkan masalah, merumuskan kesimpulan, mengumpulkan berbagai kemungkinan.

Literasi tidak hanya sekadar kemampuan membaca dan menulis, tetapi literasi bisa berarti melek teknologi, politik, berpikir kritis, dan peka terhadapi lingkungan sekitar. Menurut Kirsch \& Jungeblut dalam buku Literacy: Profile of America's Young Adult mendefinisikan literasi sebagai kemampuan seseorang dalam menggunakan informasi untuk mengembangkan pengetahuan sehingga mendatangkan manfaat bagi masyarakat (dalam Irianto dan Febrianti, 2017).

Pada awalnya, literasi dimaknai sebagai suatu keterampilan membaca dan menulis, tetapi dewasa ini pemahaman tentang literasi semakin meluas maknanya. Pemahaman terkini mengenai makna literasi mencakup kemampuan membaca, memahami, dan mengapresiasi berbagai bentuk komunikasi secara kritis, yang meliputi bahasa lisan, komunikasi tulis, komunikasi yang terjadi melalui media cetak atau pun elektronik (Wardana dan Zamzam, 2014).

Menurut Wells (dalam Heryati, dkk ,2010) terdapat empat tingkatan literasi, yaitu performative, functional, informational, dan epistemic.

Literasi tingkatan pertama adalah sekadar mampu membaca dan menulis. Literasi tingkatan kedua adalah menunjukkan kemampuan menggunakan bahasa untuk keperluan hidup atau skill for survival (seperti membaca manual, mengisi formulir, dsb). Literasi tingkatan ketiga adalah menunjukkan kemampuan untuk mengakses pengetahuan. Literasi tingkatan keempat menunjukkan kemampuan mentransformasikan pengetahuan. Literasi menjadi kecakapan hidup yang menjadikan manusia berfungsi maksimal dalam masyarakat.

Kecakapan hidup bersumber dari kemampuan memecahkan masalah melalui kegiatan berpikir kritis. Selain itu, literasi juga menjadi refleksi penguasaan dan apresiasi budaya.

Masyarakat yang berbudaya adalah masyarakat yang menanamkan nilai-nilai positif sebagai upaya aktualisasi dirinya. Aktualisasi diri terbentuk melalui interpretasi, yaitu kegiatan mencari dan membangun makna kehidupan. Hal tersebut dapat dicapai melalui penguasaan literasi yang baik.

Sementara Kuder \& Hasit (2002) mengemukakan literasi merupakan semua proses pembelajaran baca tulis yang 
dipelajari seseorang termasuk di dalamnya empat keterampilan berbahasa (mendengar, berbicara, membaca, dan menulis). Dengan berkembangnya kemampuan literasi seseorang, maka akan membantu kita memahami dunia dan mengungkapkan identitas, ide, dan budaya.

Musthafa menjelaskan bahwa literasi yang berkembang pada anak tidak hanya berkutat pada kemampuan membaca dan menulis saja, tetapi dapat diterjemahkan ke dalam berbagai atau beragam arti, sering disebut dengan multiliterasi. Terbentuknya generasi yang literat merupakan sebuah keharusan, agar bangsa kita bisa bangkit dari keterpurukan bahkan bersaing dan hidup sejajar dengan bangsa lain.

Literasi sangat berhubungan dengan kemampuan seseorang dalam membaca, menulis, berbicara, dan mengolah informasiinformasi yang diperoleh sampai kepada menyelesaikan permasalahan yang dihadapi dalam kehidupan sehari-hari.

Cara sederhana menguasai literasi adalah dengan menanamkan kebiasaan membaca. Membaca akan memberikan manfaat bagi seseorang, yaitu menambah wawasan dan pengetahuan. Menurut Sumardi (2011), fondasi untuk membangun penguasaan semua ilmu adalah kesenangan dan kebiasaan membaca. Kegemaran membaca adalah kegiatan positif yang akan membuat seseorang semakin pandai daripada seseorang yang tidak memiliki kebiasaan membaca.

Selain hal tersebut, makna literasi yang sudah berkembang mengharuskan generasi melek informasi. Melek informasi dapat diistilahkan dengan literasi informasi.

Literasi informasi dapat diartikan sebagai keberaksaraan informasi atau kemelekan informasi. American Library Association (ALA) mendefinisikan literasi informasi sebagai "information literacy is a set of abilities requiring individuals to recognize when information is needed and have the ability to locate, evaluate, and use effective needed information". Definisi tersebut dapat dimaknai bahwa literasi informasi berperan sebagai alat untuk memilah informasi-informasi yang bermanfaat.

Informasi-informasi akan disaring dengan tujuan efisien dalam berbagai aspek selama proses pencarian informasi. Jadi, dapat disimpulkan bahwa kemampuan berliterasi menjadikan generasi muda cakap dalam memilih keluwesan informasi (dalam Irianto dan Febrianti, 2017).

Fadriyani (dalam Kharizmi, 2015) menyebutkan beberapa faktor yang dapat mempengaruhi kemampuan literasi seseorang , yaitu adalah faktor intelegensi, jenis kelamin, perkembangan motorik, kondisi fisik, kesehatan fisik, lingkungan, perbedaan status sosial dan keluarga, termasuk di dalamnya adalah keterlibatan orangtua.

Reese,dkk. (dalam Kharizmi, 2015) menemukan temuan dari penelitiannya tentang perkembangan literasi bahwa keterlibatan orangtua memiliki peranan yang sangat besar dalam mengembangkan kemampuan bahasa dan literasi anak.

Tujuan dari literasi adalah diantaranya,sebagai berikut : 1). Membantu meningkatkan pengetahuan dengan cara membaca berbagai informasi 
yang bermanfaat. 2) Membantu meningkatkan tingkat pemahaman seseorang dalam mengambil kesimpulan dari informasi yang dibaca 3) Meningkatkan kemampuan seseorang dam memberikan penilaian kritis terhadap suatu karya tulis.

Sementara itu manfaat dari literasi , adalah : 1) Menambah perbendaharaan kata (kosa kata) seseorang. 2) Mendapat berbagai wawasan dan informasi baru. 3) Kemampuan dalam memaknai suatu informasi akan meningkat. 4) Meningkatkan kemampuan dalam menganalisis dan berpikir seseorang. 5) Meningkatkan kemampuan seseorang dalam merangkai kata yang bermakna

Kemampuan literasi yang tinggi sangat berpengaruh terhadap pemerolehan berbagai informasi yang berhubungan dengan usaha menjalani kehidupan (berkompetisi). elain hal tersebut, makna literasi yang sudah berkembang mengharuskan generasi melek informasi.

Melek informasi dapat diistilahkan dengan literasi informasi. Literasi informasi dapat diartikan sebagai keberaksaraan informasi atau kemelekan informasi. American Library Association (ALA) mendefinisikan literasi informasi sebagai "information literacy is a set of abilities requiring individuals to recognize when information is needed and have the ability to locate, evaluate, and use effective needed information".

Definisi tersebut dapat diartikan bahwa literasi informasi berperan sebagai alat untuk memilah informasi-informasi yang bermanfaat. Informasi-informasi akan disaring dengan tujuan efisien dalam berbagai aspek selama proses pencarian informasi. Jadi, dapat disimpulkan bahwa kemampuan berliterasi menjadikan generasi muda cakap dalam memilih keluwesan informasi.

Generasi muda akan lebih siap menjadi generasi yang mampu menghadapi tantangan masa depan dengan penguasaan literasi. Literasi informasi yang telah diungkapkan sebelumnya berfungsi agar generasi muda terampil dalam memilah dan menggunakan informasi untuk dijadikan bahan dalam pembangunan bangsanya. Penguasaan literasi tersebut juga penting agar generasi muda mengetahui perkembangan atau kemajuan informasi.

Dengan meningkatkan penguasaan literasi maka juga diharapkan ketrampilannya dalam berpikir kritis juga meningkat.

Salah satu kecakapan hidup (life skill) yang perlu dikembangkan melalui proses pendidikan adalah keterampilan berpikir.

Morgan (1999) mengutip pendapat Marzano (1992) memberikan kerangka tentang pentingnya pembelajaran berpikir yaitu: (1) berpikir diperlukan untuk mengembangkan sikap dan persepsi yang mendukung terciptanya kondisi kelas yang positif, (2) berpikir perlu untuk memperoleh dan mengintegrasikan pengetahuan, (3) perlu untuk memperluas wawasan pengetahuan, (4) perlu untuk mengaktualisasikan kebermaknaan pengetahuan, (5) perlu untuk mengembangkan perilaku berpikir yang menguntungkan.

Beberapa keterampilan berpikir yang dapat meningkatkan kecerdasan memproses dalam life skill adalah keterampilan berpikir kritis keterampilan 
mengorganisir otak, dan keterampilan analisis.

Menurut Robert Ennis dalam Fisher (2008) berpikir kritis adalah "Critical thinking is thinking that makes sense and focused reflection to decide what should be believed or done" artinya pemikiran yang yang masuk akal dan refleksi yang berfokus untuk memutuskan apa yang mesti dipercaya atau dilakukan.

Pendapat tersebut dapat diartikan bahwa pada hakekatnya saat berpikir manusia sedang belajar menggunakan kemampuan berpikirnya secara intelektual dan pada saat bersama berpikir terlintas alternatif dan solusi persoalan yang di hadapi sehingga ketika berpikir manusia dapat memutuskan apa yang mesti dilakukan karena dalam pengambilan keputusan adalah bagian dari berpikir kritis.

Menurut John Dewey dalam Kasdin (2012:3) berpikir kritis adalah adalah pertimbangan yang aktif, terus menerus dan teliti mengenai sebuah keyakinan atau bentuk pengetahuan yang diterima begitu saja dengan menyertakan alasan-alasan yang mendukung dan kesimpulankesimpulan yang rasional.

Menurut Wade (dalam Filsaime, 2008), kemampuan berpikir kritis meliputi : (1) mengajukan pertanyaan, (2) mengidentifikasi masalah, (3) menguji fakta-fakta, (4) menganalisis asumsi dan bias, (5) menghindari penalaran emosional, (6) menghindari simplikasi yang berlebihan, (7) mempertimbangkan interpretasi, dan (8) mentoleransi penafsiran ganda.

Berpikir kritis menuntut adanya usaha, rasa peduli tentang keakurasian, kemauan, dan sikap tidak mudah menyerah ketika menghadapi tugas yang sulit. Demikian pula, dari orang yang berpikir kritis ini diperlukan adanya suatu sikap keterbukaan terhadap ide-ide baru. Dan hal ini bukan sesuatu yang mudah namun harus dan tetap dilaksanakan dalam upaya mengembangkan kemampuan berpikir (Fisher, 2008).

Dengan berkembangnya kemampuan berpikir kritis maka diharapkan individu dapat berpikir secara ilmiah. Dengan Kemampuan berpikir kritis juga sangat dibutuhkan dalam menganalisis suatu permasalahan hingga pada tahap pencarian solusi untuk menyelesaikan permasalahan tersebut.

Individu yang memiliki
kemampuan berpikir kritis tidak hanya mengenal sebuah jawaban. Mereka akan mencoba mengembangkan kemungkinankemungkinan jawaban lain berdasarkan analisis dan informasi yang telah didapat dari suatu permasalahan. Berpikir kritis berarti melakukan proses penalaran terhadap suatu masalah sampai pada tahap kompleks tentang "mengapa" dan "bagaimana" proses pemecahannya.

$$
\text { Lebih lanjut dijelaskan }
$$

karakteristik dari berpikir kritis menurut Wade (dalam Setiawan, 2005) adalah menjawab pertanyaan, merumuskan masalah, meneliti fakta-fakta, menganalisis asumsi dan kesalahan, menghindari alasan-alasan yang emasional, menghindari penyederhanaan yang berlebihan, memikirkan intepretasi lain, dan mentoleransi arti ganda.

Kemampuan berpikir terutama kemampuan berpikir kritis dan kreatif sangat diperlukan dalam mengajarkan pemecahan masalah pada individu karena salah satu indikasi adanya transfer belajar 
adalah kemampuan menggunakan informasi dan ketrampilan dalam memecahkan masalah. Melalui pemecahan masalah-masalah itu individu dilatih berpikir kritis melalui latihan.

Ciri-ciri berpikir kritis menurut Cece Wijaya (dalam kompasiana, 2015), adalah: 1) Mengenal secara rinci bagianbagian dari keseluruhan; 2) Pandai mendeteksi permasalahan; 3) Mampu membedakan ide yang relevan dengan yang tidak relevan; 4) Mampu membedakan fakta dengan diksi atau pendapat; 5) Mampu mengidentifikasi perbedaanperbedaan atau kesenjangankesenjangan informasi; 6) Dapat membedakan argumentasi logis dan tidak logis; 7) Mampu mengembangkan kriteria atau standar penilaian data; 8) Suka mengumpulkan data untuk pembuktian faktual; 9) Dapat membedakan diantara kritik membangun dan merusak; 10) Mampu mengidentifikasi pandangan perspektif yang bersifat ganda yang berkaitan dengan data; 11) Mampu mengetes asumsi dengan cerrmat; 12) Mampu mengkaji ide yang bertentangan dengan peristiwa dalam lingkungan; 13) Mampu mengidentifikasi atributatribut manusia, tempat dan benda, seperti dalam sifat, bentuk, wujud, dan lain-lain; 14) Mampu mendaftar segala akibat yang mungkin terjadi atau alternatif pemecahan terhadap masalah, ide, dan situasi; 15) Mampu membuat hubungan yang berurutan antara satu masalah dengan masalah lainnya; 16) Mampu menarik kesimpulan generalisasi dari data yang telah tersedia dengan data yang diperoleh dari lapangan; 17) Mampu menggambarkan konklusi dengan cermat dari data yang tersedia; 18) Mampu membuat prediksi dari informasi yang tersedia; 19) Dapat membedakan konklusi yang salah dan tepat terhadap informasi yang diterimanya; 20) Mampu menarik kesimpulan dari data yang telah ada dan terseleksi.

Kemampuan berpikir kritis adalah kemampuan berpikir evaluatif yang memperlihatkan kemampuan manusia dalam melihat kesenjangan antara kenyataan dan kebenaran dengan mengacu kepada hal-hal ideal, serta mampu menganalisis dan mengevaluasi serta mampu membuat tahapan-tahapan pemecahan masalah, mampu menerapkan bahan-bahan yang telah dipelajari dalam bentuk perilaku sehari-hari baik di sekolah, di rumah maupun dalam kehidupan bermasyarakat sesuai dengan norma-norma yang berlaku.

Kemampuan berpikir Kritis (critical thinking) merupakam kegiatan yang sama dari pengambilan keputusan (decision making), perencanaan stratejik (strategic planning), proses ilmiah (scientific process), dan pemecahan masalah (problem solving). Berpikir kritis mengandung makna sebagai proses penilaian atau pengambilan keputusan yang penuh pertimbangan dan dilakukan secara mandiri, baik dalam proses perumusan alasan dan pertimbangan mengenai fakta, keadaan, konsep, metode dan kriteria.

\section{METODE PENELITIAN}

Penelitian ini termasuk dalam penelitian kualititaif, dengan metode yang digunakan untuk pengkajian ini adalah studi literatur. Pengumpulan data atau sumber literature diperoleh dari bukubuku teks, laporan hasil penelitian, skripsi 
dan jurnal penelitian. Data yang diperoleh kemudian dikumpulkan, dianalisis, dan disimpulkan sehingga mendapatkan kesimpulan mengenai studi literatur.

\section{HASIL DAN PEMBAHASAN}

Seseorang yang melakukan kegiatan literasi akan, mendukung keberhasilan seseorang dalam menangani berbagai persoalan. Kemampuan literasi menjadi kecakapan hidup yang menjadikan manusia berfungsi maksimal dalam masyarakat. Kecakapan hidup bersumber dari kemampuan memecahkan masalah melalui kegiatan berpikir kritis.

Berpikir kritis merupakan proses berpikir intelektual di mana pemikir dengan sengaja menilai kualitas pemikirannya, pemikir menggunakan pemikiran yang reflektif, independen, jernih, dan rasional. Menurut Halpen (dalam Achmad, 2007), berpikir kritis adalah memberdayakan keterampilan atau strategi kognitif dalam menentukan tujuan.

Proses tersebut dilalui setelah menentukan tujuan, mempertimbangkan, dan mengacu langsung kepada sasaranmerupakan bentuk berpikir yang perlu dikembangkan dalam rangka memecahkan masalah, merumuskan kesimpulan, mengumpulkan berbagai kemungkinan, dan membuat keputusan ketika menggunakan semua keterampilan tersebut secara efektif dalam konteks dan tipe yang tepat.

Berpikir kritis mempunyai makna yaitu kekuatan berpikir yang harus dibangun pada seseorang sehingga menjadi suatu watak atau kepribadian yang terpatri didalam kehidupan seseorang untuk memecahkan segala persoalan hidupnya.

Keterampilan berpikir kritis sangat penting bagi seseorang karena dengan keterampilan ini seseorang mampu bersikap rasional dan memilih alternatif pilihan yang terbaik bagi dirinya. Seseorang yang memiliki keterampilan berpikir kritis akan selalu bertanya pada diri sendiri dalam setiap menghadapi segala persoalannya untuk menentukan yang terbaik bagi dirinya. Demikian juga jika seseorang yang memiliki keterampilan berpikir kritis akan terpatri dalam watak dan kepribadiannya dan terimplementasi dalam segala aspek kehidupannya.

Dengan demikian pemberdayaan keterampilan berpikir kritis pada seseorang sangat mendesak dilakukan yang dapat terintegrasi melalui metodemetode pembelajaran yang akan terbukti mampu memberdayakan keterampilan berpikir kritis seseorang (Hadi, 2007).

Berpikir kritis dapat muncul kapan pun dalam peroses penilaian, keputusan, atau penyelesaian masalah secara umum. Kapan pun seseorang berusaha untuk mengetahui apa yang perlu dipercaya, apa yang perlu diketahui alasannya. Proses pengolahannya melalui usaha dan reflektif seperti membaca, menulis, berbicara dan mendengar semua dapat dilakukan secara kritis. Berpikir kritis sangat penting agar dapat menggunakan potensi pikiran secara optimal sehingga menjadi individu dapat menghasilkan keputusan dengan benar.

Kemampuan berpikir kritis dapat ditingkatkan melalui latihan. Terdapat delapan langkah yang dapat membantu seseorang atau orang yang ingin 
meningkatkan kemampuannya dalam berpikir kritis, yaitu: (a) menentukan masalah atau isu nyata, proyek, atau keputusan yang betul-betul dipertimbangkan untuk dikritisi; (b) menentukan poin-poin yang menjadi pandangan; (c) memberikan alasan mengapa poin-poin itu dipertimbangkan untuk dikritisi; (d) membuat asumsiasumsi yang diperlukan; (e) bahasa yang digunakan harus jelas; (f) membuat alasan yang mendasari dalam fakta-fakta yang meyakinkan; (g) mengajukan kesimpulan; dan (h) menentukan implikasi dari kesimpulan tersebut.

\section{SIMPULAN}

Literasi harus menjadi budaya yang ditanamkan sejak dini sehingga menghasilkan para kompeten yang mampu memahami, melibati, menggunakan, menganalisis, dan mentrasformasikan informasi yang ada.

Hal tersebut dapat menjadikan seseorang mampu mengenali dan mengembangkan potensi diri sebagai upaya meningkatkan kualitas diri sehingga mampu bersaing dengan dunia luar, untuk dapat meningkatkan kemampuan literasi ini, individu harus menjadikan literasi sebagai budaya yang ditanamkan sejak dini sehingga menghasilkan para kompeten yang mampu memahami, melibati, menggunakan, menganalisis, dan mentrasformasikan informasi yang ada.

Hal tersebut dapat menjadikan seseorang mampu mengenali dan mengembangkan potensi diri sebagai upaya meningkatkan kualitas diri sehingga mampu bersaing, dengan kemampuan literasi yang baik, maka diharapkan kemampuan berpikir kritispun akan meningkat.

Kemampuan berpikir kritis merupakan suatu proses berpikir yang dapat diterima akal reflektif yang diarahkan untuk memutuskan apa yang dikerjakan atau diyakini, dalam hal ini tidak sembarangan, tidak membawa ke sembarang kesimpulan tetapi kepada ke kekesimpulan yang terbaik.

Manfaat kemampuan berpikir kritis dalam pembelajaran sangat besar peranannya dalam meningkatkan proses dan hasil belajar. Selain manfaat kemampuan berpikir kritis dalam pembelajaran juga mempunyai peranan sebagai bekal individu untuk menghadapi masa depan. Beberapa penelitian membuktikan manfaat kemampuan berpikir kritis dalam pembelajaran maupun sebagai bekal masa depan.

Kemampuan berpikir kritis merupakan suatu proses yang digunakan dalam kegiatan mental,seperti pengambilan keputusan, pemecahan masalah, menganalisa asumsi sampai dengan melakukan penelitian ilmiah. Dan hal ini berkaitan dengan kemampuan seseorang dalam literasi, dengan literasi yang dilakukan individu seperti dengan membaca atau menyimak informasi atau cerita ,maka individu dapat menemukan cara dalam menyelesaikan masalah, sehingga individu akan melakukan analisis dari permasalahannya tersebut, sehingga pada akhirnya akan membentuk karakter atau pribadi yang kritis.

\section{DAFTAR PUSTAKA}

Achmad, Arief. (2007). Memahami Berpikir Kritis. Diunduh di http://researchengines.com/1007arief3.html / 10 Desember 2019 
Arti Literasi adalah : Pengertian, Tujuan, Manfaat dan Jenis Literasi, Diunduh di https:www.maxmanroe.com/vid/umu/artiliterasi-adalah.html / 13 Desember 2019

Farihatin, Anisa Rohmati. 2013. Kegiatan Membaca Buku Cerita dalam Pengembangan Kemampuan Literasi Dasar Anak Usia Dini. Skripsi Universitas Muhammadiyah Surakarta : Tidak Diterbitkan

Fisher. A. 2008. Berpikir Kritis "Sebuah Pengantar".Jakarta: Erlangga.

Heryati, Y., dkk. (2010). Model Inovatif Pembelajaran Bahasa Indonesia. Jakarta: Multi Kreasi Satudelapan

Irianto, P. O., \& Febrianti, L. Y. (2017, June). Pentingnya penguasaan literasi bagi generasi muda dalam menghadapi MEA. In Proceedings Education and Language International Conference (Vol. 1, No. 1).

Kenapa Harus Berpikir Kritis, 2015, diunduh di https://www.kompasiana.com / tanggal 20 Desember 2019

Kasdin, Sitohang. dkk. 2012. Critical Thinking "Membangun Pemikiran Logis" Jakarta: Pustaka Sinar Harapan

Kharizmi, M. 2015. Kesulitan Seseorang Sekolah Dasar Dalam Meningkatkan Kemampuan Literasi . Jupendas, ISSN 2355-3650, Vol. 2, No. 2, September 2015

Kompas. Rabu, 1 Juni 2016. "Budayakan Literasi". Pendidikan dan Kebudayaaan. Hlm. 12

Kuder, S Jay \& Cindi Hasit. 2002. Enhancing Literacy for All Students. USA: Pearson Education Inc

Musthafa, Bachrudin. 2014. Literasi Dini dan Literasi Remaja: Teori, Konsep, dan Praktik. Bandung: CREST.

Sumardi. (2011). Rahasia menjadi Seseorang Unggul. Jakarta: Erlangga.

Susanto, Hadi. 2013. Kemampuan Berpikir Kritis. Diunduh di https ://bagawanabiyasa,wordpress.com / tanggal 22 Desember 2019

Tjalla, Awaluddin. 2011. Potret Mutu Pendidikan Indonesia Ditinjau dari Hasil-hasil Studi Internasional. 